\title{
Durabilitas Blok Beton Sandwich dengan Isian Styrofoam di Lingkungan Agresif
}

\author{
Aditya Kenanga; M. Rizky Darmawan; \\ Rr. M. I. Retno Susilorini dan David Widianto \\ adityakenanga2704@gmail.com dan rizkydarmawan612@gmail.com \\ Program Studi Teknik Sipil, Fakultas Teknik \\ Universitas Katolik Soegijapranata, Semarang
}

\begin{abstract}
The research aimed to observe durability of sandwich concrete block with styrofoam in aggressive environment which was modeled by curing media. The curing media used in this research are plain water, sea water, brakish water, and tidal flooding water. The curing was conducted for 28 days and followed by compressive strength test. The result of this research found that maximum compressive strength was 1,76 MPa with tidal flooding water as curing media, followed by 1,67 MPa with brakish water as curing media, and also 1,64 MPa with sea water as as curing media, and the lowest compressive strength was 1,36 MPa with plain water as as curing media.
\end{abstract}

Keywords: durability, block, sandwich concrete, styrofoam, compressive strength, aggressive environment

\begin{abstract}
ABSTRAK
Penelitian ini bertujuan untuk mengetahui durabilitasblok beton sandwich dengan isian styrofoam yang terhadapa lingkungan agresif yang dimodelkan denganmedia perendaman. Media yang digunakan dalam penelitian ini adalah air tawar, air laut, air payau, dan air "rob" (air pasang yang masuk ke daratan). Perendaman benda uji dilakukan selama 28 hari. Prosesperendaman dilanjutkan dengan pengujian kuat tekan. Hasil penelitian menunjukkan bahwa kuat tekan maksimal adalah sebesar 1,76 MPa pada media perendaman air rob, diikuti 1,67 MPa pada media perendaman air payau, kuat tekan yang lebih rendah diperoleh pada media perendaman air laut dengan sebesar 1,64 MPa dan kuat tekan terendah sebesar 1,36 $\mathrm{MPa}$ pada media perendaman air tawar.
\end{abstract}

Kata kunci: durabilitas, blok, beton sandwich, styrofoam, kuat tekan, lingkungan agresif 


\section{Pendahuluan}

Indonesia adalah salah satu negara yang memiliki jumlah penduduk terpadat dan memilikibanyak wilayah. Secara geografis Indonesia terletak di antara benua Asia dan Australia, berada di antara dua samudera Samudra Pasifik dan Samudra Hindia. Indonesia merupakan salah satu negara maritim yang cukup besar di dunia. Prasarana yang ada di desain sesuai dengan kebutuhan yang sesuai dengan kondisi alam. Salah satu contohnya adalah pembangunan di sekitar pesisir pantai yang menuntut inovasi struktur beton yang tahan dengan air laut.

Beton memiliki berat jenis yang tinggi sehingga beban mati yang dibebankan pada struktur menjadi tinggi, inovasi pada teknologi beton sangat dibutuhkan pada perkembangan kontruksi saat ini yang dituntut untuk ramah lingkungan dan memiliki berat jenis yang rendah (beton ringan). Berat jenis beton ringan kurang dari 1900 kg/cm3 (Putra, 2015).

Pembuatan beton ringan sangat dibutuhkan sebuah inovasi material campuran yang memiliki berat jenis yang rendah. Alternatif yang dapat diaplikasikan adalah styrofoam, hal ini dikarenakan styrofoam memiliki berat jenis yang rendah.

Styrofoam atau expanded polystyrene digunakan untuk campuran beton maka berat beton akanlebih ringan dan nilai guna styrofoam akan bertambah, namun akan berpengaruh pada kekuatan beton tersebut.Harganya pun cukup murah. Styrofoam atau expanded polystyrene yang terbuat dari polisterin atau gabus putih sering menjadi limbah industri maupun limbah rumah tangga yang menjadi permasalahan lingkungan karena sifatnya yang tidak dapat terurai dan membusuk.

Berdasarkan hal diatas, maka dilakukan penelitian terhadap "DURABILITAS BLOK BETON SANDWICH DENGAN ISIAN STYROFOAM DI LINGKUNGAN AGRESIF" untuk mengetahui seberapa besar pengaruh styrofoam pada campuran beton, adapun karakteristik yang dimaksud adalah kekuatan mekanik beton yang mencakup kuat tekan, kuat tarik, kuat lentur dengan berbagai macam kondisi, seperti kondisi air tawar, air payau, air laut dan air rob.

Penelitian ini merupakan bagian dari penelitian payung Susilorini dan Widianto (2018), "Inovasi Teknologi Beton SandwichStyrofoam" yang didanai oleh PT Indostar Modular."

\section{Tinjauan Pustaka}

\subsection{Beton}

Beton merupakan salah satu bahan konstruksi yang telah umum digunakan untuk bangunan gedung, jembatan, jalan, dan lain lain. Beton ini didapatkan dengan cara mencampur agregat halus (pasir), agregat kasar (kerikil), atau jenis agregat lain dan air, dengan semen portland atau semen hidrolik yang lain, bisa juga ditambahkan dengan bahan tambah (additive) yang bersifat kimiawi pada perbandingan tertentu sampai menjadi satu kesatuan (Putra, 2015).

Nilai kuat tekan beton relatif lebih tinggi dibandingkan kuat tariknya, dan beton merupakan bahan bersifat getas. Nilai kuat tariknya hanya berkisar antara 9\%-15\%(Lie, 2017). Umumnya beton yang diperkuat dengan tulangan baja akan bekerjasama dalam menahan gaya yang bekerja dimana tulangan baja menahan gaya tarik sedangkan beton sebagai penerima gaya tekan.

Faktor yang mempengaruhi kekuatan beton bermacam-macam salah satunya yaitu:

a. bahan-bahan campuran yang dipakai apakah sesuai dengan standart yang berlaku dan dengan komposisi yang baik pula, 
b. cara pengerjaan beton juga sangat penting karena sebagai pacuan hasil akhir beton itu sendiri,

c. perawatan dan keadaan lingkungan dimana beton diterapkan.

Setiap beton memiliki sifat yang dipengaruhi beberapa faktor alami namun dengan mengetahui sifat bahan bakunya maka dapat diketahui kebutuhan dari masing-masing bahan baku dan berapa kekuatannya (Lie, 2017).

Tingkat mutu beton yang akan dicapai memiliki perbandingan campuran beton yang ditentukan agar beton yang dihasilkan dapat memberikan hasil sebagai berikut:

a) Kemudahan dalam pengerjaan (workability)

b) Ketahanan terhadap kondisi lingkungan yang agresif (sifat tahan lama dan sifat kedap air).

\subsection{Beton Komposit}

Komposit adalah suatu jenis bahan yang dihasilkan dari rekayasa yang terdiri dari dua bahan atau lebih(Wiyono \& Faimun, 2013), sifat masing-masing bahan berbeda, baik sifat kimia maupun fisika nya dan tetap terpisah dalam hasil akhir bahan tersebut (Wiyono \& Faimun, 2013). Dengan adanya perbedaan dari material penyusun maka komposit antar material harus berkaitan dengan kuat. Material komposit akan bersinergi bila memiliki sebuah sistem yang menyatukan material-material penunjang untuk menjadi sebuah sifat material baru.

Komposit yang akan digunakan dalam penelitian kali ini adalah penggabungan antara bahan styrofoam dan beton.

Gabungan dari styrofoam dan beton juga dapat menjadi satu material kontruksi sistem komposit. Dengan asumsi styrofoam dan beton akan bekerja dalam memikul beban yang bekerja pada suatu struktur, sehingga dapat menghasilkan desain yang lebih ekonomis (Yudha, 2013)

Keunggulan beton komposit adalah (Yudha, 2013):

1) Bahan komposit styrofoam dan beton memiliki kepadatan yang jauh lebih rendah dibanding dengan bahan konvensional, dan memiliki kekuatan yang lebih tinggi,

2) Dari segi berat beton komposit styrofoam dan beton jauh lebih ringan dibandingkan dengan beton konvensional,

3) Mudah dibentuk saat pengerjaannya, sehingga tidak menyulitkan saat proses pengerjaannya,

4) Lebih kuat dan tidak getas,

5) Lebih ekonomis dibandingkan beton konvensional.

Kelemahan beton komposit adalah (Yudha, 2013):

1) Kurang tahan terhadap cuaca ekstrim,

2) Belum ada software khusus untuk menganalisa dan mendesain material komposit,

3) Lebih sulit dibentuk secara plastis.

\subsection{Beton Ringan}

Beton normal memiliki beban yang cukup berat, dengan berat sendiri yaitu $2400 \mathrm{~kg} / \mathrm{m} 3$. Untuk mengurangi bebannya pada suatu struktur bangunan maka telah banyak digunakan beton ringan. Menurut SNI 03-2847 tahun 2002, beton dapat digolongkan sebagai beton ringan jika beratnya kurang dari 1900 kg/m3(BSN, 2002). Dalam pembuatan beton ringan sangat dibutuhkan material yang ringan. Pada umumnya berat jenis yang lebih ringan 
dapat dicapai jika berat beton diperkecil yang berpengaruh pada menurunnya kekuatan beton tersebut. Pembuatan beton ringan pada prinsipnya adalah membuat rongga didalam beton. Semakin banyak rongga udara dalam beton semakin ringan beton yang dihasilkan.

Secara umum kandungan udara mempengaruhi kekuatan beton. Kekuatan beton berkurang 5.5\% dari kuat tekan setiap pemasukan udara $1 \%$ dari volume campuran. Beton dengan bahan pengisi udara mempunyai kekuatan $10 \%$ lebih kecil daripada beton tanpa pemasukan udara pada kadar semen dan workabilitas yang sama. Pada beton dengan kekuatan menengah dan tinggi, tiap $1 \%$ peningkatan kandungan udara akan mengurangi kekuatan tekan beton sekitar 5\% tanpa perubahan air semen (Putra, 2015).

Styorofoam pada penelitian ini berfungsi sebagai pembentuk rongga pada beton sehingga peneliti tidak terfokus pada durabilitas styrofoam. Namun secara umum beton ringan memiliki standar yang berhubungan dengan durabilitas yakni "Freezing and Thawing Test for Concrete, Method A" berdasarkan JIS A1148. Hal ini berhubungan dengan faktor lingkungan yang agresif kususnya dengan lingkungan yang langsung terkena air laut, air payau, dan air rob sedangkan air tawar digunakan sebagai pembanding. Pengujian dilakukan dengan cara melakukan perendaman dengan menggunakan 4 jenis air, air laut, air payau, air rob dan air tawar, dengan 5 benda uji di masing-masing jenis air. Namun hasil pengujian tidak bisa menunjukan secara akurat tentang ketahanan beton ringankarena hal ini disebabkan oleh beberapa factor yaitu durasi siklus cuaca, temperatur minimum, dan perubahan temperatur(Putra, 2015).
Beton ringan dapat dibagi lagi dalam tiga golongan berdasarkan tingkat kepadatan dan kekuatan beton yang dihasilkan dan berdasarkan jenis aggregat ringan yang dipakai. Klasifikasi beton ringan menurut Winter dan Nilson (1993), yang dituliskan oleh Suamita (2012):

- Beton insulasi (Insulating Concrete). Beton ringan dengan berat (density) antara $300 \mathrm{~kg} / \mathrm{m} 3$ - $800 \mathrm{~kg} / \mathrm{m} 3$ dan berkekuatan tekan berkisar 0,69 6,89 MPa,

- Beton ringan dengan kekuatan sedang (Moderate Strength Concrete). Beton ringan dengan berat (density) antara $800 \mathrm{~kg} / \mathrm{m} 3$ $1440 \mathrm{~kg} / \mathrm{m} 3$,

- Beton Struktural (Structural Concrete). Beton ringan dengan berat (density) antara $1440 \mathrm{~kg} / \mathrm{m} 3$ $1850 \mathrm{~kg} / \mathrm{m} 3$

\subsection{Beton Sandwich}

Struktur sandwich merupakan struktur yang terdiri dari dua lapisan tipis, kaku dan kuat dari material padat yang dipisahkan oleh satu lapisan tebal yang terbuat dari material dengan berat jenis yang rendah, yang memiliki kekakuan dan kekuatan yang lebih rendah dari lapisan pengapitnya. Dua lapisan tipis yang terdapat pada struktur sandwich ini disebut dengan lapisan kulit, dan satu lapisan tengah disebut dengan lapisan inti(Firdaus, 2012).Pada kebanyakan kasus, sebuah struktur sandwich yang efisien didapat bila berat inti dari sandwich kira-kira sama dengan jumlah berat lapisan pengapitnya. Pada umumnya lapisan kulit berupa beton normal yang mempunyai kekakua yang tinggi. Sedangkan pada lapisan inti berupa beton ringan yang memiliki kekakuan rendah, namun memiliki kinerja rangkak yang tinggi (Firdaus, 2012). 
kekuatan yang tinggi terhadap semen, serat kaca harus memiliki kadar $\mathrm{ZrO}_{2}$ sebanyak $16 \%$ dari keseluruhan berat.

\section{Semen}

Semen yang digunakan adalah semen portland biasa dan harus disimpan dengan benar dan kering

\section{Agregat Halus}

Gambar 1. Struktur Beton Sandwich.

\subsection{Glassfiber Reinforced Concrete (GRC)}

Glassfiber Reinforced Concrete (GRC) adalah jenis beton yang terbuat dari fine grained concrete (matriks beton) dan diberi perkuatan serat yang terdistribusi secara merata ke seluruh volume beton atau bagian-bagian tertentu. Gabungan beton dan serat dipastikan melalui ikatan sepanjang permukaannya, memberikan sebuah derah kontak serat-beton yang besar, hal ini menghasilkan sifat baru dari GRC (Zakki, 2015).

GRC memiliki sifat proses yang baik, dapat dicetak dalam berbagai bentuk sesuai dengan aplikasinya, tahan terhadap retak, lentur, tahan air, dan dapat di bentuk dengan mudah untuk finishing dekoratif. GRC sendiri mudah dipelihara, memiliki sifat permeabilitas yang rendah dan dapat mengurangi beban pada struktur bangunan.

Pembuatan GRC dapat dilakukan dengan dua metode, dengan cara disemprot dengan adukan biasa. GRC terdiri dari beberapa material pembentuk, komponen utama adalah semen, agregat halus, admixture, acrylic polimer. Berikut ini adalah uraian bahanbahan penyusun GRC:

\section{Serat Kaca Anti Alkali}

Serat kaca haruslah berupa filamen yang anti alkali yang dikembangkan dan diformulasikan agar memiliki

Pasir yang digunakan harus dalam kondisi bersih (sudah dicuci, dan dikeringkan), agar perbandingan air dengan pasir dapat akurat. Pasir harus memiliki permukaan yang halus, tanpa ada partikel-partikel kecil yang kasar, sebisa mungkin menggunakan uji saring no 100, untuk GRC yang disemprot ukuran partikel maksimumya $1,2 \mathrm{~mm}$, sedangkan yang dicampur langsung 2,4 mm. jumlah campuran pasir tidak boleh 50 $\%$ dari berat keseluruhan campuran, perbandingan pasir adalah 1:2.

4. Air

Air harus dalam kondisi bersih dan tidak tercemar bahan kimia, hal ini untuk mencegah kerusakan pada GRC, akibat sifat kimiawi.

5. Admixture

Admixture dapat diberikan pada campuran GRC, sesuai dengan standar yang berlaku. Penggunaan superplasticiser dianjurkan untuk menjaga kadar air tetap minimum tanpa kehilangan karakteristik dari komposit tersebut.

\subsection{Semen Portland}

Semen adalah sebuah zat yang berfungsi sebagai bahan perekat batu bata, batako dan bahan bangunan lainnya yang akan digabungkan menjadi satu. Semen sendiri berasal dari kata caementum (bahasa latin) yang memiliki arti memotong dan menjadikan bagianbagian kecil tak beraturan (Putra, 2015). 
Dikutip dari Kamus Besar Bahasa Indonesia semen adalah kumpulan serbuk yang terbuat dari kapur dan menjadi satu dengan material lainnya yang berfungsi untuk membuat betonm merekatkan batu bata maupun untuk membuat sebuah tembok (Tjokrodimuljo, Teknologi Beton, 2003).Dalam pengertiannya secara umum semen adalah bahan yang memiliki dua sifat yaitu adhesive dan cohesive, berfungsi sebagai bahan pengikat (bonding material), yang nantinya digunakan bersama-sama dengan batu kerikil dan pasir.

Semen sendiri digolongkan dalam dua kelompok sebagai berikut:

a. Semen non hidraulis (BSN, 2002)

Semen non hidraulis dalah semen yang memiliki sifat tidak dapat mengeras didalam air dan tidak akan bisa stabil jika berada didalam air. Salah satu contoh semen non hidraulis (hydraulic binder) adalah lime atau perekat klasik dalam sebuah bangunan yang terbuat dari hasil pemanasan bahan limestone hingga suhu mencapai $850^{\circ} \mathrm{C}$. Setelah proses pemanasan maka $\mathrm{CaCO}_{3}$ dari limestone akan melepaskan kandungan $\mathrm{CO}_{2}$ yang pada akhirnya akan menghasilkan burn lime atau quick lime $(\mathrm{CaO})$.

$$
\mathrm{C}_{3} \mathrm{CO}_{3}+\mathrm{H}_{2} \mathrm{O} \longrightarrow \mathrm{C}_{\mathrm{a}}(\mathrm{OH})_{2}+\mathrm{CO}_{2}
$$

Semen hidraulis sendiri bereaksi sangat cepat dengan air yang menghasilkan $\mathrm{Ca}(\mathrm{OH})_{2}$ berbentuk seperti butiran halus dan $\mathrm{Ca}(\mathrm{OH})_{2}$ akan dapat mengeras jika zat ini bereaksi dengan $\mathrm{CO}_{2}$ lalu dapat membentuk $\mathrm{CaCO}_{3}$ kembali.

b Semen hidraulis (BSN, 2002)

Semen jenis ini berbanding terbalik dengan semen non hidraulis karena semen hidraulis sifatnya dapat mengeras ketika berada didalam air dan menghasilkan padatan yang lebih stabil. Karena bersifat hidraulis maka semen ini memiliki sifat sebagai berikut:

- Sifatnya mudah mengeras jika dicampur dengan air

- Tidak mudah larut ketika berada di dalam air

- Dapat mengeras meskipun didalam air

Contoh dari semen hidraulis sendiri adalah, semen Portland, semen campur, dan semen khusus.

\subsubsection{Jenis-Jenis Semen}

Sesuai dengan (BSN, 2002) selain semen hidraulis dan non hidraulis tersebut terbagi lagi dalam klasifikasi jenis-jenis semen sebagai berikut:

a. Semen putih (Gray Cement)

Semen putih memiliki kandungan campuran zat yang berbeda dengan semen abu karena jenis semen putih ini lebih murni dan biasanya dipakai pada akhir pekerjaan (finishing). Bahan utama untuk pembuatan semen putih yaitu memakai kalsit (calcite) limestone murni.

b. Semen sumur minyak (Oil Well Cement)

Bahan utama untuk pembuatan jenis semen sumur minyak sendiri tentunya berbeda dengan lainnya karena fungsinya juga dikhususkan untuk proses pengeboran minyak bumi atau gas alam, baik pengeboran di darat maupun di lepas pantai.

c. Semen Portland

Semen portland atau hidraulis diproses dengan menghasilkan klinker yang berasal dari kandungan silikatsilikat kalsium (mudah mengeras bila bercampur dengan air) dan menggunakan gips untuk bahan tambahnya sendiri. 
Semen yang digunakan dalam dunia konstruksi atau pembangunan umumnya memakai semen tipe I dengan kekurangan dan keterbatasan sifat semen yang mempengaruhi mutu mortar pada hasil akhirnya.

\subsubsection{Unsur-Unsur Semen (SNI 15- 2049-2004 Semen Portland)}

Unsur-unsur semen portland antara lain:

1. Trikalsium silikat $\left(\mathrm{C}_{3} \mathrm{~S}\right)$ Sifatnya sangat mudah mengeras jika ditambahkan dengan air maka trikalsium silikat ini akan mengeras dan kaku dalam hitungan jam dan pasta akan mengeras.

2. Dikalsium silikat $\left(\mathrm{C}_{2} \mathrm{~S}\right)$

Setelah ditambahkan dengan air pasta yang mengeras kekuatannya dapat stabil namun dalam beberapa minggu kemudian kekuatannya lambat hingga mencapai kekuatan tekan akhir.

3. Trikalsium aluminat $\left(\mathrm{C}_{3} \mathrm{~A}\right)$

Trikalsium aluminat sendiri jika bereaksi dengan air maka zat jenis ini menghasilkan panas hidrasi yang tinggi.

4. Tetrakalsium aluminoferit $\left(\mathrm{C}_{4} \mathrm{AF}\right)$ Pada saat semen bereaksi kimia dengan air yang membentuk masa padat ini belum bisa diketahui secara mendetail karena sifat reaksi kimia semen ini sendiri sangat kompleks

\subsection{Agregat Halus (Pasir)}

Agregat halus adalah agregat berupa pasir dan semua butirannya harus dapat menembus ayakan 4,80 mm, harus memenuhi spesifikasi agregat untuk beton sesuai dengan metode ASTM - C 33 dan SNI-03-2461-1991 spesifikasi agregat untuk beton struktur sesuai ASTM - C 330.

Agregat halus dapat berisi pasir alam maupun pasir olahan bahkan dapat berupa gabungan antara kedua pasir tersebut sperti yang sudah dijelaskan dalam peraturan SNI 03 - 032847 2002 yaitu syarat dapat dikatakan agregat halus jika butiran-butiran agregat memiliki ukuran tidak lebih dari $5 \mathrm{~mm}$ dan lolos saringan no.4 (Putra, 2015).

Pasir alam dapat dibedakan menjadi tiga golongan sebagai berikut:

\section{Pasir galian}

Pasir jenis ini didapatkan langsung dengan cara menggali langsung pada permukaan tanah dengan memakai alat bantu untuk memudahkan dalam mengambil pasir ini. Pasir galian biasanya bersudut tajam, memiliki pori, dan bebas dari kandungan garam di dalamnya

2. Pasir sungai

Pasir sungai didapatkan langsung dari dasar sungai, berbentuk sperti butiran halus dan bulat-bulat akibat adanya gesekan dan daya lekat antar butiran kurang kuat karena butiran berbentuk bulat

\section{Pasir pantai}

Pasir pantai adalah pasir yang diperoleh dari tepi pantai bentuknya bulat dan berbutir halus karena terkena gesekan antar agregat. Pasir pantai sendiri banyak mengandung garam yang menyebabkan kondisi pasir selalu agak basah, maka pasir pantai merupakan pasir yang jelek jika digunakan untuk membuat sebuah bangunan (Dumyati, 2015).

\subsection{Air}

Air adalah bahan dasar pembuatan beton yang berfungsi untuk membuat semen bereaksi dan sebagai bahan pelumas antara butir-butir agregat. Pada umumnya air minum dapat dipakai untuk campuran beton. Air yang tercemar garam, minyak, gula atau bahan kimia lainnya, bila dipakai untuk campuran beton akan sangat menurunkan kekuatannya dan dapat juga mengubah sifat-sifat semen (Dumyati, 2015). 
Gambar 2. Lokasi Pengambilan Contoh

Air Laut Di Pantai Marina.

\subsubsection{Air Tawar}

Air tawar dalam penelitian ini murni air tawar tanpa campuran yang diambil dari air sumur di Laboratorium Bahan dan Bangunan Teknik Sipil Unika Soegijapranata, air tawar sendiri adalah air yang tidak mempunyai rasa. Hal ini dikarenakan air ini mengandung garam dan mineral dalam jumlah yang sedikit sekali. Air tawar merupakan air yang dapat diminum dan aman dikonsumsi oleh manusia. Air tawar dapat ditemukan di sumur, sungai, danau, dan salju serta waduk, bendung, dan bendungan.

\subsubsection{Air Laut}

Sumber garam yang terdapat di air laut berasal dari pelapukan batu-batuan dan tanah. Ketika air mengalir melalui sungai ke laut, air tersebut sebenarnya sudah mengandung garam namun dalam jumlah yang sangat sedikit. Begitu pula saat ombak laut menerjang karang juga menghasilkan garam mineral yang berasal dari bebatuan. Lama-kelamaan garam-garam yang terkumpul ini akan semakin banyak sehingga menyebabkan air laut terasa asin (Yudianto, 2000).

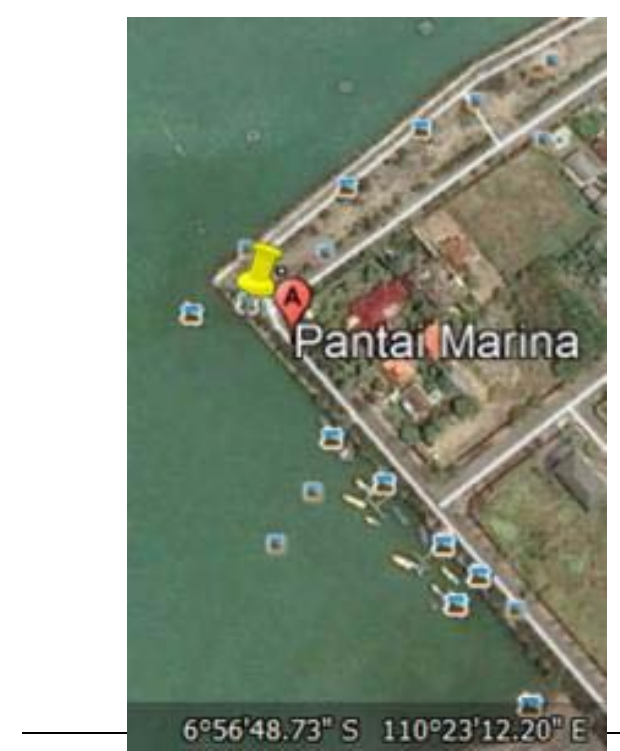

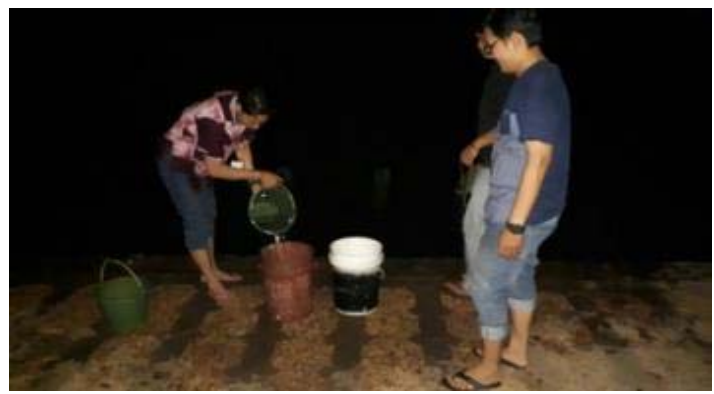

Gambar 3. Proses Pengambilan Contoh Air Laut.

Sumber garam yang terdapat di air laut berasal dari pelapukan batu-batuan dan tanah. Ketika air mengalir melalui sungai ke laut, air tersebut sebenarnya sudah mengandung garam namun dalam jumlah yang sangat sedikit. Begitu pula saat ombak laut menerjang karang juga menghasilkan garam mineral yang berasal dari bebatuan. Lama-kelamaan garam-garam yang terkumpul ini akan semakin banyak sehingga menyebabkan air laut terasa asin (Yudianto, 2000).

\subsubsection{Air Payau}

Air payauadalah air yang berasal dari percampuran dari air tawar dan air laut/air asin. Suatu air bisa dikatakan bersifat payau apabila kandungan garam mineral di dalam setiap liternya berkisar antara 0,5-30 gram. Air payau biasanya bisa dijumpai di daerah-daerah muara sungai tetapi dalam penelitian ini menggunakan campuran antara air tawar dan air laut dengan perbandingan 1:1 (Hartono, 2009).

\subsubsection{Air Rob}

Air rob dapat disimpulkan air yang berasal dari laut yang naik ke daratan, komposisi air rob tidak jauh berbeda dengan air laut, hanya saja kondisi air rob biasanya akan lebih tercemar 
dibandingkan dengan air laut, hal ini di karenakan air telah bercampur dengan limbah yang ada didaratan (Yudianto, 2000).

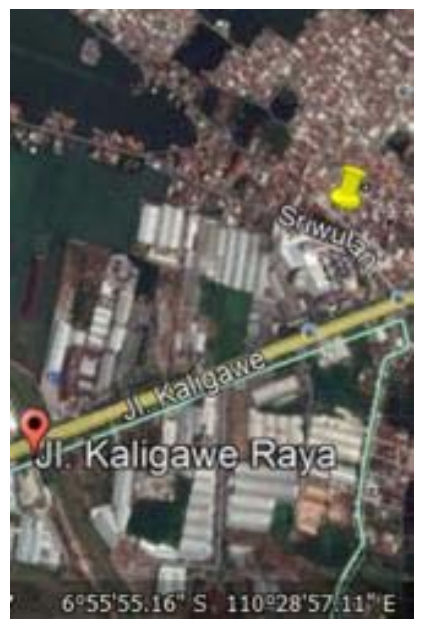

Gambar 4. Lokasi Pengambilan Contoh Air Rob di Desa Sriwulan.

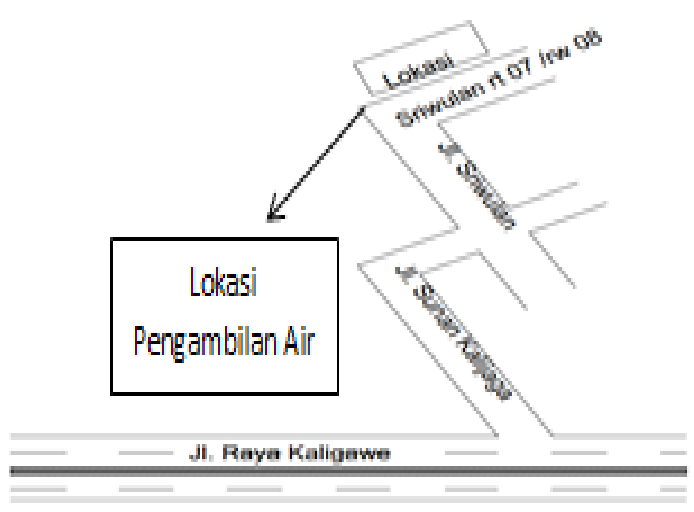

Gambar 5. Petunjuk Arah Menuju Desa Sriwulan, Kecamatan Sayung, Demak.

\subsection{Styrofoam}

Styrofoam yang memiliki nama lain polystyrene, banyak digunakan dalam kehidupan sehari-hari. Pada umumnya Styrofoam digunakan sebagai bahan pembungkus makanan, elektronik. Hal ini dikarekan sifat styrofoam ringan, praktis, tidak mudah rusak. Polystyrene ini dihasilkan dari styrene $\left(\mathrm{C}_{6} \mathrm{H}_{5} \mathrm{H}_{9} \mathrm{CH}_{2}\right)$ yang mempunyai gugus phenyl yang tersusun secara tidak teratur sepanjang garis karbon dari molekul. Styrofoam ini memiliki berat jenis sampai $1050 \mathrm{~kg} / \mathrm{m} 3$, kuat tarik sampai $40 \mathrm{MN} / \mathrm{m} 2$, dan modulus lentur sampai $3 \mathrm{GN} / \mathrm{m} 2$, modulus geser sampai $0,99 \mathrm{GN} / \mathrm{m} 2$, angka poison 0,33. Styrofoam memiliki berat satuan yang kecil yaitu 13-22 $\mathrm{kg} / \mathrm{m} 2$. Sehingga Styrofoam dalam campuran beton sangat cocok untuk mendapatkan berat jenis beton yang ringan (Irdhiani \& Ramadhani, 2014).

Penggunaan styrofoam dalam beton dapat dianggap sebagai rongga udara. Namun keuntungan menggunakan styrofoam dibandingkan dengan rongga udara dalam beton berongga adalah styrofoam mempunyai kuat tarik. Kerapatan atau berat jenis beton dengan campuran styrofoam dapat diatur dengan mengontrol jumlah campuran styrofoam dalam beton (Irdhiani \& Ramadhani, 2014).

\subsection{Durabilitas Beton}

Durabilitas atau ketahanan adalah suatu kondisi dimana beton menghadapi segala macam kondisi, tanpa mengalami kerusakan selama jangka waktu umur pemakaian beton. beton yang demikian disebut juga dengan beton mutu tinggi. Berkurangnya durabilitas beton disebabkan oleh beberapa faktor, diantaranya sebagai berikut (Suamita, 2012).

1. Pengaruh fisik, pelapukan oleh cuaca

a. Membeku dan mencair, terjadi pada pasta semen dan agregat

b. Basah dan kering, terjadi pada pasta semen

c. Perubahan temperatur yang drastis, terjadi pada pasta semen dan agregat

2. Pengaruh kimia, campuran unsur kimia kedalam beton

a. Reaksi alkali-agregat, terjadi pada agregat

b. Serangan asam dan alkalis, terjadi pada pasta semen 
c. Serangan sulfat, terjadi pada pasta semen

\section{Pengaruh mekanis}

a. Abrasi, pengkikisan yang terjadi pada agregat dan pasta semen

b. Perubahan volume akibat perbedaan sifat thermal dari agregat terhadap pasta semen.

Ciri-ciri beton dengan durabilitas adalah (Dumyati, 2015):

a. Tahan terhadap pengaruh lingkungan

b. Memiliki umur yang panjang

c. Kepadatan struktur tinggi

d. Permeabilitas rendah

e. Porositas rendah

Kegagalan struktur beton selalu dihubungkan dengan durabilitas beton. Dengan kondisi lingkungan yang ekstim beton akan mengalami kegagalan dengan munculnya retakan pada material beton.Dalam penelitian ini kekuatan beton akan diuji dengan menggunakan metode perendaman terlebih dahulu dan akan dilakukan pengetesan kuat tekan, kuat tarik belah dan kuat lentur. Perendaman dilakukan dengan 4 macam jenis air yang berbeda, air tawar, air payau, air laut dan air rob, lamanya waktu perendaman bervariasi 28 hari.

\subsection{Kuat Tekan}

Parameter yang menunjukkan besarnya beban persatuan luas yang menyebabkan benda uji rusak oleh gaya tekan tertentu disebut kuat tekan. Kuat tekan menjadi parameter untuk menentukan mutu dan kualitas beton yang ditentukan oleh agregat, perbandingan semen, dan perbandingan jumlah air. Pembuatan beton akan berhasil jika dalam pencapaian kuat tekan beton telah sesuai dengan yang telah direncanakan dalam mix design (SNI-1974-2011).

\section{Metodologi Penelitian}

\subsection{Diagram Alir Penelitian}

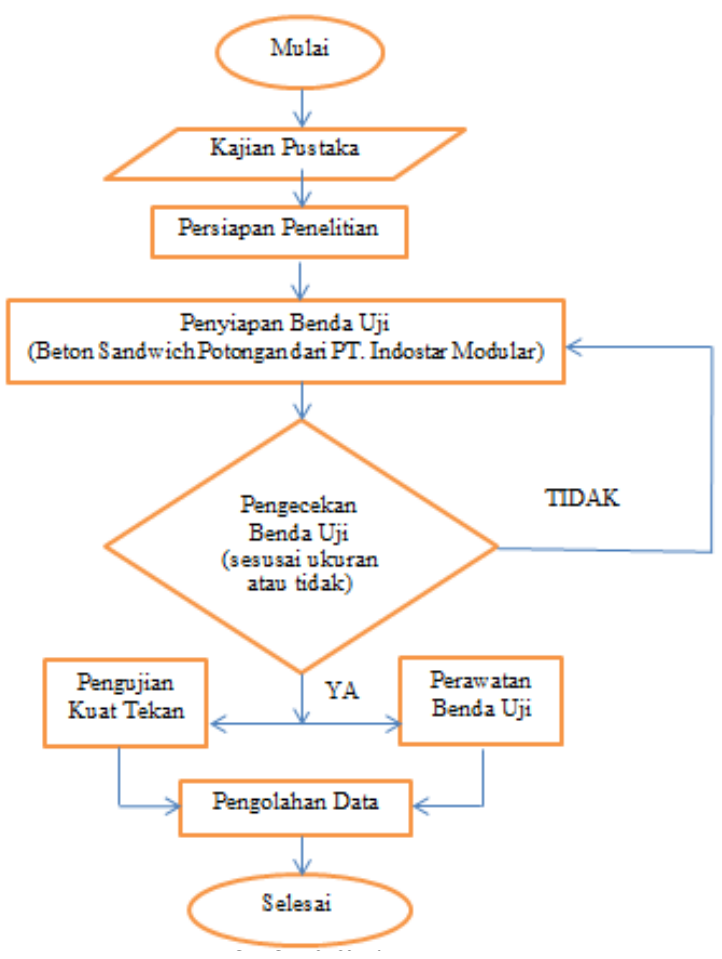

\subsection{Tempat Penelitian}

Penelitian ini dilakukan di Laboratorium Struktur Teknik Sipil Universitas Katolik Soegijapranata yang beralamat di Jl. Pawiyatan Luhur IV No.1, Bendan Dhuwur, Tinjomoyo, Banyumanik, Kota Semarang.

\subsection{Rancangan Benda Uji dan Jumlah Benda Uji}

Benda uji dibuat sedemikian rupa membentuk panel sandwich dengan ukuran $\mathrm{p}=240 \mathrm{~cm}, \mathrm{l}=60 \mathrm{~cm}, \mathrm{t}=7,5 \mathrm{~cm}$ yang dipotong berbentuk blok beton oleh owner tanpa ada campur tangan dari pihak peneliti dengan dimensi: $\mathrm{p}=37 \mathrm{~cm}$, $\mathrm{l}=15,5 \mathrm{~cm}, \mathrm{t}=7,5 \mathrm{~cm}$. Dengan jumlah sebanyak 20 buah, masing-masing jenis 
media perendaman mendapatkan jumlah sebanyak 5 benda uji.

\subsection{Bahan Penelitian}

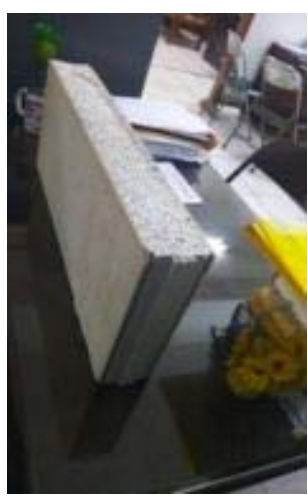

Gambar 7. Potongan Blok Beton Sandwich.

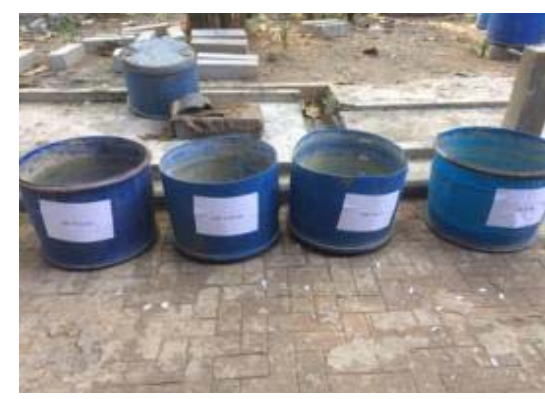

Gambar 8. Media Perendaman.

Pada Gambar 8 ukuran bak perendaman memiliki diameter $60 \mathrm{~cm}$ dan dapat menampung masing-masing jumlah benda uji sesuai jenis media perendaman yang digunakan sampai benda uji terendam sepenuhnya.

\subsection{Alat Penelitian}

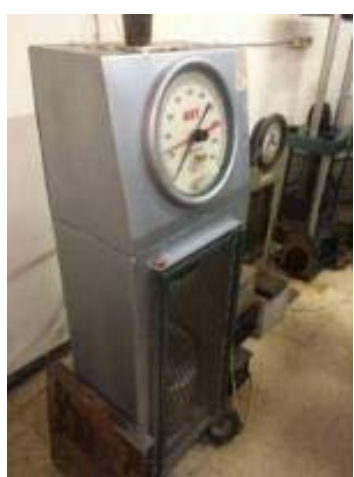

Gambar 9. Compression Machine

Tipe CO-325.4 dengan kapasitas tekan $2000 \mathrm{kN}$.

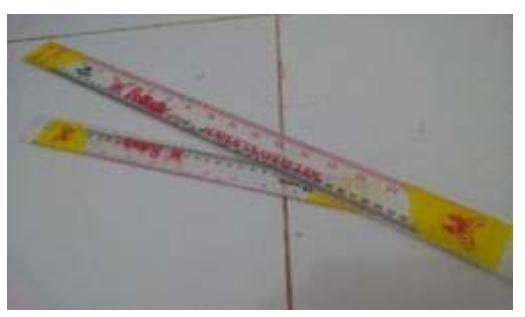

Gambar 10. Mistar Ukur.

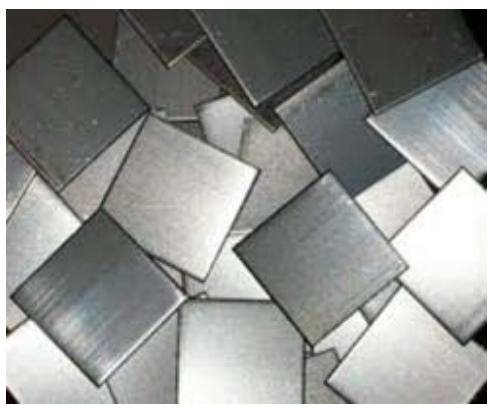

Gambar 11. Lempeng Baja.

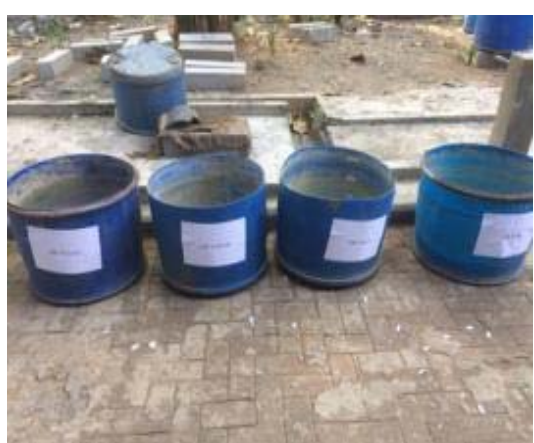

Gambar 12. Bak Air Perendam.

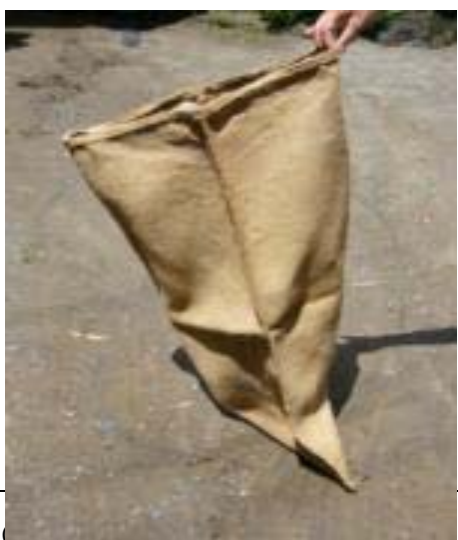

G-SMART Jurnal Teknik Sipil Unika Soegijapranata Semarang | ISSN : 2620-5297 Volume 1 | Nomor 2 | Desember 2017 
Gambar 13. Karung Goni (Sebagai penutup ketika dilakukan perendaman).

\subsection{Dimensi Benda Uji}

Benda uji blok beton sandwich dengan isian styrofoam yang dipotong berbentuk blok beton dengan dimensi $\mathrm{p}$ $=37 \mathrm{~cm}, \mathrm{l}=15,5 \mathrm{~cm}, \mathrm{t}=7,5 \mathrm{~cm}$. Dengan jumlah sebanyak 20 buah, masingmasing jenis media air mendapatkan jumlah sebanyak 5 buah.

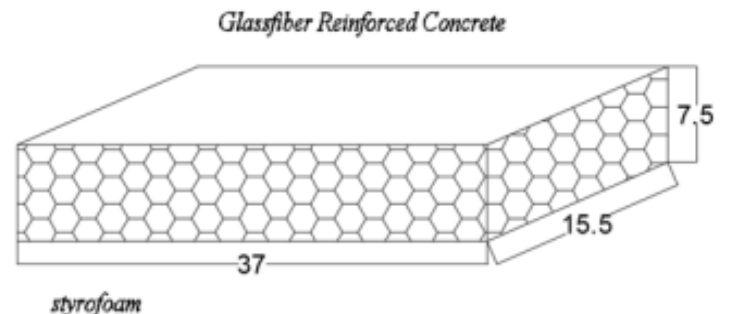

\section{Gambar 14. Dimensi Blok Beton Sandwich}

\subsection{Persiapan Pengujian}

Pengujian benda uji dilakukan dengan metode perendaman didalam kolam atau bak perendaman, benda uji direndam kedalam bak perendam sampai blok beton terendam secara keseluruhan, perendaman dilakukan dengan jenis air yang berbeda-beda.

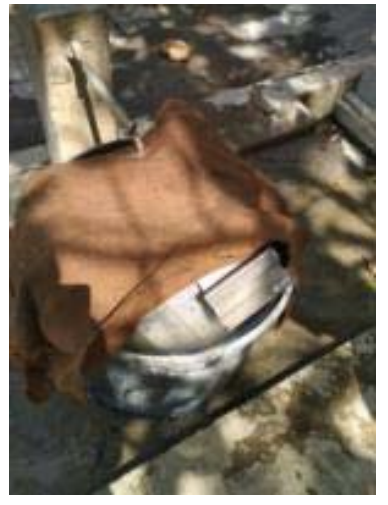

Gambar 15. Proses Perendaman.

Benda uji ini direndam selama 28 hari untuk mengetahui pengaruh lama perendaman yang akan di uji dengan kuat tekan benda uji untuk mendapatkan fungsi lama waktu perendaman dengan kekuatan tekan benda uji.

\subsection{Metode Perendaman}

Perendaman dilakukan dengan cara merendam benda uji didalam bak perendaman, benda uji direndam kedalam bak perendam sampai blok beton terendam secara keseluruhan dan menggunakan karung goni sebagai penutup atas supaya blok beton selalu dalam keadaan basah dan terendam, perendaman dilakukan dengan jenis air yang berbeda-beda.

Benda uji ini direndam selama 28 hari untuk mengetahui pengaruh lama perendaman yang akan di uji dengan kuat tekan benda uji untuk mendapatkan fungsi dari perbedaan media perawatan dengan hasil kuat tekan benda uji.

\subsection{Metode Pengujian Benda Uji}

Dalam penelitian beton dalam tugas akhir ini kami menggunakan metode pengujian yaitu uji kuat tekan. Pengujian ini dilakukan untuk mengetahui kuat tekan beton yang telah dimodifikasi dengan penambahan bahan campuran styrofoam. Beban yang digunakan adalah beban maksimal sampai blok beton hancur dan dicatat besarnya beban maksimal.

Langkah-langkah pengujian kuat tekan sebagai berikut:

1. Benda uji yang telah direndam dengan masing-masing jenis media air yang di modelkan dan pada umur yang telah ditentukan, kemudian dientaskan dari rendaman air dan diangin-anginkan sampai benda uji kering sehingga benda uji bisa dilanjutkan proses pengujian kuat tekan beton sandwich.

2. Setelah dilakukan pengujian kuat tekan maka akan didapatkan hasil beban maksimal sampai blok beton 
styrofoam hancur dan dicatat besarnya beban maksimal yang diperoleh.

\section{Hasil dan Pembahasan}

\subsection{Hasil Uji Kuat Tekan Blok Beton Sandwich}

Pengujian kuat tekan blok beton sandwichsetelah masa perendaman 28 hari dilakukan pada semua benda uji yang telah selesai proses perendaman. Pada media perendaman air tawar nilai kuat tekan tertinggi mencapai 1,92 $\mathrm{MPa}$ benda uji dengan kode AT-NS-5 dan 0,96 $\mathrm{MPa}$ merupakan nilai kuat tekan terendah dengan kode benda uji AT-NS3 , media perendaman air payau nilai kuat tekan tertinggi mencapai 2,01 $\mathrm{MPa}$ benda uji dengan kode AP-NS-5 dan 1,05 MPa merupakan nilai kuat tekan terendah dengan kode benda uji AP-NS1 , media perendaman air rob nilai kuat tekan tertinggi mencapai $115 \mathrm{kN}$ benda uji dengan kode AR-NS-4 dan 1,56 MPa merupakan nilai kuat tekan terendah dengan kode benda uji AR-NS-1, media perendamann air laut nilai kuat tekan tertinggi mencapai 1,92 MPa benda uji dengan kode AL-NS-3 dan 1,05 $\mathrm{MPa}$ merupakan nilai kuat tekan terendah dengan kode benda uji AL-NS-2.

Rumus perhitungan untuk mencari kuat tekan blok beton sandwichadalah sebagai berikut:

$$
\text { G }(\text { Kuat Tekan })=\frac{P}{A}
$$

Keterangan:

$$
\begin{aligned}
& \mathrm{P}=\text { Gaya tekan } \\
& \mathrm{A}=\text { Luas penampang }
\end{aligned}
$$

\subsubsection{Hasil Pengujian Kuat Tekan Blok Beton Sandwich dengan Masa Perendaman 28 Hari}

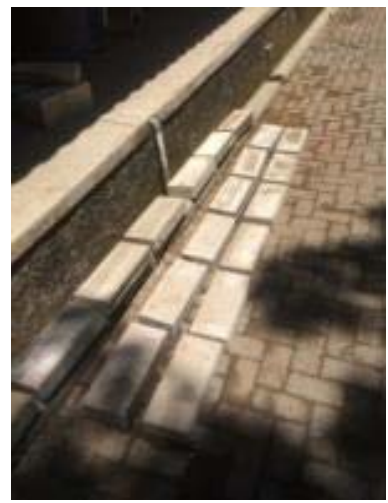

Gambar 16. Benda UjiBlok Beton Sandwichdengan Masa Perendaman 28 Hari.

Gambar 16 merupakan benda ujiblok beton sandwich yang telah direndam selama 28 hari dalam air tawar, air rob, air payau, dan air laut dengan jumlah benda uji sebanyak dua puluh dan diangin-anginkan sampai kering lalu dilanjutkan dengan pengujian kuat tekan.

\subsection{Pembahasan}

Hasil pengujian laboratorium dan pengolahan data yang kami lakukan, kami mendapatkan pembahasan mengenai kuat tekan masing-masing benda uji dengan media perendaman air yang berbeda sebagai berikut:

\subsubsection{Kuat Tekan}

Berikut adalah grafik hasil dari pengujian kuat tekan blok beton sandwich dengan isian styrofoam yang telah diolah. 


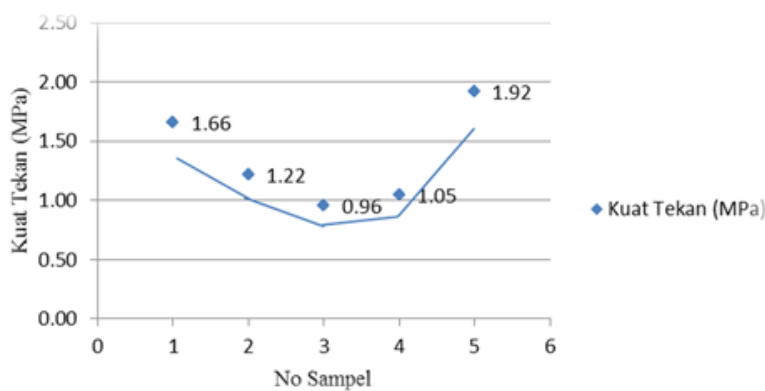

Gambar 17.Pengujian Kuat Tekan, dengan Media Perendaman Air Tawar.

Pengujian kuat tekan blok beton sandwich dengan media perendaman air tawar, memiliki kuat tekan paling besar dengan nilai 1,92 MPa, sedangkan yang memiliki kuat tekan paling rendah dengan nilai $0,96 \mathrm{MPa}$.

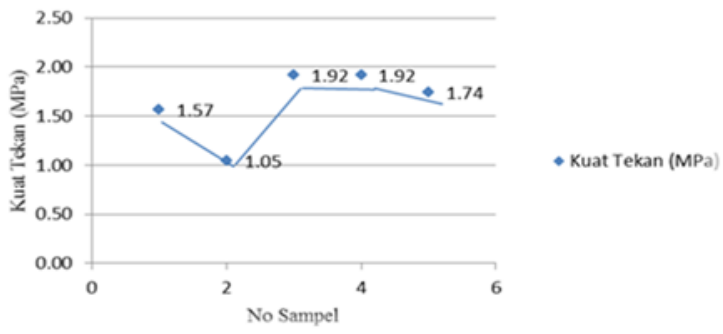

Gambar 18. Pengujian Kuat Tekan, dengan Media Perendaman Air Laut.

Pengujian kuat tekan blok beton sandwich dengan media perendaman air laut, memiliki kuat tekan paling besar dengan nilai 1,92 MPa sedangkan yang memiliki kuat tekan paling rendah dengan nilai $1,05 \mathrm{MPa}$.

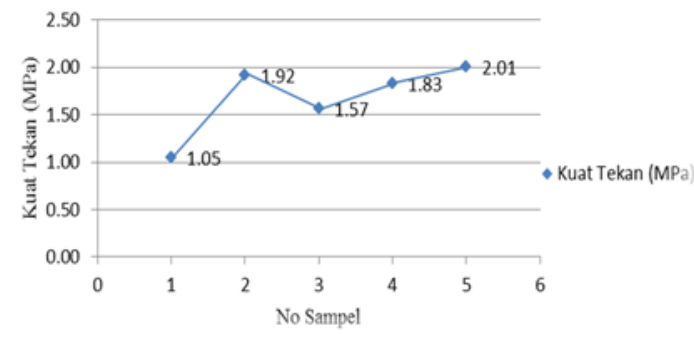

Gambar 19 Pengujian Kuat Tekan, dengan Media Perendaman Air Payau.

Pengujian kuat tekan blok beton sandwich dengan media perendaman air payau, memiliki kuat tekan paling besar dengan nilai, 2,01 MPa sedangkan yang memiliki kuat tekan paling rendah dengan nilai $1,05 \mathrm{MPa}$.

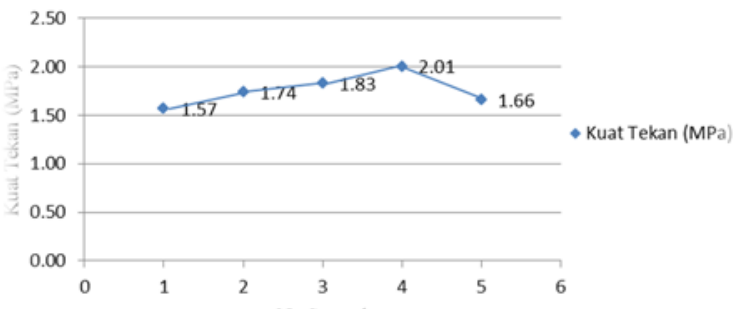

Gambar 20.Pengujian Kuat Tekan, dengan Media Perendaman Air Rob.

Pengujian kuat tekan blok beton sandwich dengan media perendaman air payau, memiliki kuat tekan paling besar dengan nilai 2,01 MPa, sedangkan yang memiliki kuat tekan paling rendah dengan nilai 1,57 MPa.

Berikut adalah grafik rata-rata hasil dari pengujian kuat tekan blok beton sandwich dengan isian styrofoam yang telah diolah sebagai berikut:

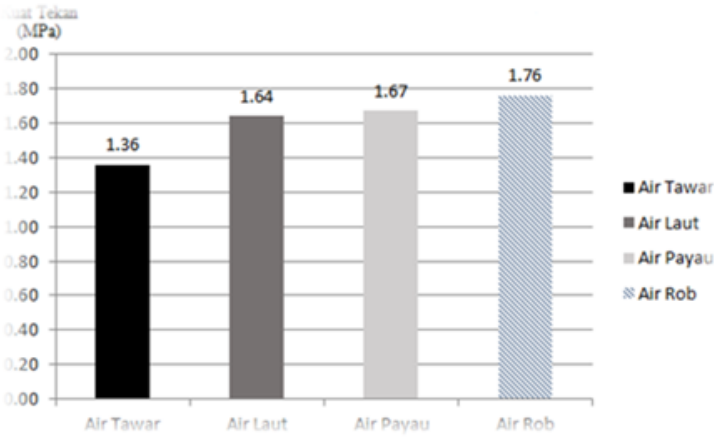

Gambar 21. Hasil Rata-rata PengujianKuat Tekan.

Benda uji yang dilakukan perendaman di air payau dan air rob memiliki kuat tekan yang lebih tinggi 
dibandingkan benda uji yang dilakukan perendaman di air tawar dan air laut, hal ini dikarenakan kandungan mineral air payau dan air rob mengisi rongga-rongga pada benda uji. Untuk perendaman di air tawar tidak ada kandungan mineral yang mengisi rongga-rongga pada benda uji, sedangkan pada air laut kandungan garam menyebabkan kekuatan benda uji menjadi rendah. Kandungan yang mengisi pada benda uji dapat mempengaruhi hasil dari kuat tekan blok beton sandwich itu sendiri, sedangkan kandungan garam yang ada di dalam air laut bersifat merusak pada benda uji.

\section{Kesimpulan dan Saran}

\subsection{Kesimpulan}

Dari peneltian ini dapat diambil beberapa kesimpulan sebagai berikut:

1. Pada benda uji yang menggunakan media perendaman air tawar kuat tekan maksimal adalah 1,92 $\mathrm{MPa}$ pada benda uji nomor 5 dengan kode AT-NS-5 dan kuat tekan terendah pada benda uji nomor 3 dengan kode AT-NS-3 sebesar 0,96 MPa,

2. Pada benda uji yang menggunakan media perendaman air laut kuat tekan maksimal adalah 1,92 MPa pada benda uji nomor 3 dan 4 dengan kode AL-NS-3, AL-NS-4 dan kuat tekan terendah pada benda uji nomor 2 dengan kode AL-NS-2 sebesar 1,05 $\mathrm{MPa}$,

3. Pada benda uji yang menggunakan media perendaman air payau kuat tekan maksimal adalah 2,01 $\mathrm{MPa}$ pada benda uji nomor 5 dengan kode AP-NS-5 dan kuat tekan terendah pada benda uji nomor 1 dengan kode AP-NS-1 sebesar 1,05 MPa,

4. Pada benda uji yang menggunakan media perendaman air rob kuat tekan maksimal adalah 2,01 MPa pada benda uji nomor 4 dengan kode AR-
NS-4 dan kuat tekan terendah pada benda uji nomor 1 dengan kode ARNS-1 sebesar 1,57 MPa,

5. Kuat tekan maksimal sebesar 1,76 $\mathrm{MPa}$ diperoleh pada media perendaman air rob, diikuti 1,67 MPa pada media perendaman air payau, kuat tekan yang lebih rendah diperoleh pada media perendaman air laut dengan sebesar 1,64 MPa dan kuat tekan terendah sebesar 1,36 MPa pada media perendaman air tawar.

\subsection{Saran}

Beberapa saran yang dapat penyusun sampaikan dari penelitian "Durabilitas Blok Beton Sandwich dengan Isian Styrofoam Di Lingkungan Agresif” yang sudah dilakukan ini adalah sebagai berikut:

a. Penelitian terhadap beton ringan dengan isian styrofoam ini dapat ditingkatkan untuk mendapatkan hasil nilai kuat tekan yang lebih tinggi karena hasil kuat tekan maksimal yang diperoleh sangat rendah,

b. Sifat-sifat struktural yang lain pada beton sandwich ini juga perlu diteliti karena berbeda dari beton normal,

c. Perlu dilakukan penelitian lebih lanjut dengan melakukan penerapan ke lapangan agar mengetahui sifat-sifat beton sandwich pada saat sudah di aplikasikan di lapangan.

\section{Daftar Pustaka}

Firdaus. (2012). Perilaku Elemen Beton Sandwich Terhadap Pengujian Geser Murni. Konfrensi Nasional Teknik Sipil. Diakses pada 7 Juli 2017 dari https://sipil.ft.uns.ac.id/konteks7/pr osiding/036S.pdf. 
Irdhiani, \& Ramadhani, S. (2014). DESAIN FONDASI TELAPAK DENGAN MENGGUNAKAN BETON STYROFOAM RINGAN PADA TANAH LEMPUNG BERPASIR. INFRASTRUKTUR. Diakses pada 6 Mei 2017 dari http://jurnal.untad.ac.id/jurnal/inde x.php/JTSI/article/download/4823/ 3669.

Lie, H. A. (2017). Teknologi Bahan. Semarang: Universitas Diponogoro. Diakses pada 8 Agustus 2017 dari http://fib-indonesia.org/wpcontent/uploads/2017/09/pengantar -Beton.pdf.

Nayiroh, N. (2017). Teknologi Material Komposit. Diakses pada 10 Juli 2017 dari http://nurun.lecturer.uinmalang.ac.id/wpcontent/uploads/sites/7/2013/03/Ma terial-Komposit.pdf.

Putra, A. F. (2015). KARAKTERISTIK BETON RINGAN DENGAN BAHAN PENGISI STYROFOAM. Tugas Akhir. Diakses pada 7 Juli 2017 dari http://repository.unhas.ac.id/bitstrea m/handle/123456789/16322/TUGA S\%20AKHIR\%20BETON\%20ST YROFOAM.pdf?sequence $=1$.

SNI 15-2049-2004. Semen Portland.

SNI 1947:2011. Cara Uji Kuat Tekan Beton.

SNI 2847:2013. Persyaratan Beton Struktural Untuk Bangunan Gedung.

Suamita, I. W. (2012). Karakteristik Beton Ringan Menggunakan Tempurung Kelapa Sebagai Bahan Pengganti Agregat Kasar. Diakses pada 9 Juli 2017 dari https://www.academia.edu/476306 7/KARAKTERISTIK_BETON_RI NGAN_DENGAN_MENGGUNA KAN_TEMPURUNG_KELAPA_S
EBAGAI_BAHAN_PENGGANTI AGREGAT_KASAR.

Susilorini, Rr. M. I. R, Widianto, D. (2018). "Inovasi Teknologi Beton Sandwich dengan Isian Styrofoam." Laporan Akhir. Program Studi Teknik Sipil, Unika Soegijapranata.

Wiyono, P., \& Faimun. (2013). ANALISA PELAT DAN BALOK MULTI LAYER MENGGUNAKAN LAMINASI. TEKNIK POM ITS Vol 1. Diakses pada 12 Agustus 2017 dari https://media.neliti.com/media/publ ications/142546-ID-analisislendutan-seketika-danlendutan.pdf.

Yudha, R. Y. (2013). Hotel Kapsul di M.H Thamrin - Jakarta Pusat Dengan Eksplorasi Dinding Sandwich Panel. Diakses pada 2 agustus 2017 dari http://docplayer.info/storage/64/505 77138/50577138.pdf.

Zakki, A. F. (2015). STUDI EKSPERIMEN MATERIAL GRC (GLASSFIBER REINFORCED CONCRETE) SEBAGAI BAHAN DASAR PADA MODULAR FLOATING PONTOON. Jurnal Teknik Perkapalan. Diakses pada 8 agustus 2017 dari http://download.portalgaruda.org/ar ticle.php?article $=441650 \& v a l=468$ 8\&title=STUDI\%20EKSPERIME N\%20MATERIAL\%20GRC\%20( GLASSFIBER\%20REINFORCED \%20CONCRETE)\%20SEBAGAI \%20BAHAN\%20DASAR\%20PA DA\%20MODULAR\%20FLOATI NG\%20PONTOON. 